\title{
PENDAMPINGAN KAJIAN REVISI PERATURAN MENTERI KOMUNIKASI DAN INFORMATIKA NOMOR 22 TAHUN 2013
}

\author{
SRI DEWI ANGGADINI ${ }^{1 *}$, TENRI HAERIYAH ${ }^{2}$, MEGA SILVIA $^{3}$ \\ Program Studi Akuntansi ${ }^{1,2,3}$ \\ Universitas Komputer Indonesia \\ Jl. Dipati Ukur No. 112-116, Bandung 40132 \\ *e-mail: sri.dewi@email.unikom.ac.id
}

\begin{abstract}
The purpose of this community service activity is to assist in the study of the revision of the text of the Minister of Communication and Informatics Regulation regarding the implementation of Universal Postal Services in accordance with the Act. In addition to these objectives, it also includes a draft regulatory text that includes the following criteria: mechanism, program planning, monitoring, supervision, verification and evaluation so as to create an accountable LPU implementation. The method of community service activities is carried out descriptively with a survey approach to several locations for the Universal Postal Service, through several stages including: preparation, collection of related data and information, data processing and analysis, preparation of technical recommendations as well as discussions, socialization and recommendations. In the implementation process, activities are carried out starting from collecting field verification data and documents, data processing and analysis, as well as compiling PM LPU revisions. The PKM activities carried out provide benefits in the form of producing a text of the Minister of Communication and Informatics Regulation on the implementation of Universal Postal Services that is in line with the Law. Through the implementation of PKM, it is hoped that the postal administration is in accordance with the expectations and needs of the community, the Government needs to take concrete and quite populist steps to support the postal administration to be carried out properly, effectively, efficiently and accountably, including the need to provide guidance and protection for postal operators, determine requirements strict rules for the feasibility of postal operators, guarantees for the reliability of products and types of postal services, preventing monopolistic practices in postal administration and community participation in postal operations.
\end{abstract}

Key words: Regulation, Kominfo, Universal Postal Service

\begin{abstract}
ABSTRAK
Tujuan dari kegiatan pengabdian kepada masyarakat ini adalah pendampingan kajian revisi naskah Peraturan Menteri Kominfo tentang penyelenggaraan Layanan Pos Universal yang selaras dengan Undang-Undang. Disamping tujuan tersebut juga meliputi rancangan naskah regulasi yang mencakup kriteria : mekanisme, perencanaan program, monitoring, pengawasan, verifikasi dan evaluasi sehingga terciptanya penyelenggaraan LPU yang akuntabel. Metode kegiatan pengabdian kepada masyarakat dilakukan secara deskriptif dengan pendekatan survey ke beberapa lokasi penyelenggaraan Layanan Pos Universal, melalui beberapa tahapan antara lain : persiapan, pengumpulan data dan informasi terkait, pengolahan data dan analisa, penyusunan rekomendasi teknis serta diskusi, sosialisasi dan rekomendasi. Dalam proses pelaksanaannya, kegiatan dilakukan mulai dari pengumpulan data verifikasi lapangan dan
\end{abstract}


dokumen, pengolahan data dan analisis, serta menyusun revisi PM LPU. Kegiatan PKM yang dilakukan memberikan manfaat berupa dihasilkannya naskah Peraturan Menteri Kominfo tentang penyelenggaraan Layanan Pos Universal yang selaras dengan Undang-Undang. Melalui pelaksaaan PKM, diharapkan penyelenggaraan pos sesuai dengan harapan dan kebutuhan masyarakat, Pemerintah perlu mengambil langkah-langkah yang konkret dan cukup populis guna mendukung penyelenggaraan pos terlaksana secara baik, efektif, efisien dan akuntabel diantaranya perlu melakukan pembinaan dan perlindungan terhadap penyelenggara pos, penentuan persyaratan yang tegas bagi kelayakan penyelenggara pos, jaminan atas keandalan produk dan jenis layanan pos, mencegah timbulnya praktik monopoli dalam penyelenggaraan pos dan keterlibatan peran serta masyarakat dalam penyelenggaraan pos.

Kata kunci: Peraturan, Kominfo, Layanan Pos Universal

\section{PENDAHULUAN}

Layanan Pos Universal (LPU) yang berlangsung dengan sangat dinamis sejalan dengan perubahan lingkungan ekonomi global dan laju kemajuan teknologi di masyarakat, mendorong lahirnya lingkungan LPU yang jauh berbeda dengan keadaan yang telah berlaku begitu lama sebelumnya. Luas daerah layanan dari suatu titik layanan yang melebihi jarak kapasitas layanan suatu titik layanan yang diakibatkan karena Penerapan Kebijakan Program Pemerintah Pusat kepada Pemerintah Daerah memberikan, mengatur, dan mengolah otoritas serta mengembangkan pemerintahan di daerah mengakibatkan perubahan daerah layanan menjadi lebih luas sehingga melebihi kapasitas layanan suatu titik layanan. Akibat yang ditimbulkan dari perkembangan atau pemekaran suatu wilayah tersebut dapat menurunkan kapasitas layanan yang selama ini dimaksimalkan untuk melayani masyarakat pada daerah jangkauan terluar di pelosok daerah. Maka diperlukan pemetaan lokasi/ titik layanan yang sesuai kondisi pertumbuhan penduduk dan perkembangan perekonomian masyarakat tempat dimana berdirinya kantor layanan yang membawahi titik-titik layan jaringan layanan terluar/ tersier.

Titik layanan POS diperlukan untuk mengetahui kapasitas Penyelenggara POS dalam melayani masyarakat karena jangkauan LPU dapat mencakup seluruh wilayah Negara
Kesatuan Republik Indonesia, lalu dapat memungkinkan kita (masyarakat) mengirim/ menerima pengiriman, dan juga dapat mengirim dari satu tempat ke tempat lain di belahan dunia. Titik layanan tentunya bersifat dinamis dan dapat bertambah ataupun berkurang sesuai dengan keadaan pasar ataupun tuntutan ekonomi, sosial, dan politik. Titik layanan diharapkan dapat mencakup seluruh titik wilayah sampai ke perbatasan wilayah Indonesia. Bantuan Operasional Layanan Pos Universal pemerintah bertanggungjawab terhadap kelangsungan pelaksanaan Bantuan Operasional Layanan Pos Universal, yaitu dengan memberikan kompensasi melalui pemberian Dana kompensasi kepada penyelenggara dalam Anggaran Pendapatan dan Belanja Negara di Mata Anggaran 999.08 (Belanja lain-lain), yang disebut dengan Bantuan Operasional Layanan Pos Universal yang diberikan sesuai dengan kriteria yang dituangkan dalam Peraturan Menteri Kominfo Nomor 22 Tahun 2013 tentang Penyelenggaraan Layanan Pos Universal yang dapat dipertanggungjawabkan secara transparan dan akuntabel [3].

Dalam hal penyelenggaraan Bantuan Operasional Layanan Pos Universal sebelum melakukan pembayaran maka terlebih dahulu diverifikasi atas pertanggungjawaban penggunaan dana tersebut secara akuntabel. Namun dalam pelaksanaannya ada hal-hal 
yang menjadi rekomendasi yang ditemukan oleh Auditor BPK RI bahwa Penentuan basis pemberian Bantuan Operasional Layanan Pos Universal yang belum selaras dengan UU No. 38 tahun 2009 terkait Pos [1]. Pelaksanaan Bantuan Operasional Layanan Pos Universal (BO LPU) Belum sesuai ketentuan; Metode Transfer Pricing, Atribusi perhitungan pendapatan dan biaya serta Metode verifikasi yang dilakukan secara sampling, atas rekomendasi tersebut perlu dilakukan revisi Peraturan Menteri Kominfo Nomor 22 Tahun 2013 tentang Penyelenggaraan LPU.

Sasaran dari kegiatan ini adalah rancangan kebijakan dan regulasi penyelenggaraan Layanan Pos Universal yang tepat, akurat, dan akuntabel yang mendukung pembangunan dan pertumbuhan perekonomian. Kami melakukan pendampingan kajian ini bersama PT. PROGRESSIVA yang merupakan konsultan independen yang mempunyai pengalaman yang sangat luas di bidang telekomunikasi, yang telah mengerjakan beberapa studi mengenai regulasi kebijakan pentarifan jasa telekomunikasi, aspek pasar jasa layanan telekomunikasi, tarif retail dan tarif interkoneksi, studi kelayakan usaha bisnis telekomunikasi, perencanaan jaringan telekomunikasi fixed dan mobile, pengawasan pembangunan dan manajemen konstruksi pembangunan jaringan telekomunikasi baik fixed maupun mobile [5]. (Permenkominfo, 2008) Tabel 1 merupakan data Jumlah Kantor Pos Cabang Layanan Pos Universal (KPC LPU).

Tabel 1. Jumlah Kantor Pos Cabang Layanan Pos Universal (KPC LPU)

\begin{tabular}{|c|l|c|c|}
\hline NO & \multicolumn{1}{|c|}{ DIVISI REGIONAL } & \multicolumn{1}{|c|}{ JUMLAH KPRK } & JUMLAH KPC IPU \\
\hline 1 & \multicolumn{1}{|c|}{} & 3 & 4 \\
\hline 1 & NAD, SUMUT & 19 & 223 \\
\hline 2 & SUMBAR, RIAU, KEPRI & 15 & 137 \\
\hline 3 & BENGKULU, JAMBI, SUMSEL, LAMPUNG, BABEL & 16 & 199 \\
\hline 4 & BANTEN, BOGOR, BEKASI & 10 & 64 \\
\hline 5 & AAWA BARAT TANPA BOGOR, BEKASI & 17 & 233 \\
\hline 6 & AAWA TENGAH, DIY & 33 & 475 \\
\hline 7 & AAWA TIMUR & 27 & 376 \\
\hline 8 & BALI, NTB, NTT & 14 & 135 \\
\hline 9 & KALIMANTAN & 19 & 210 \\
\hline 10 & SULAWESI & 13 & 170 \\
\hline 11 & PAPUA, MALUKU & 10 & 56 \\
\hline & \multicolumn{1}{|c}{ JUMLLAH NASIONAL } & 193 & 2.278 \\
\hline
\end{tabular}

\section{Tujuan/ Kegunaan}

Adapun tujuan dari kegiatan ini adalah pendampingan kajian revisi naskah Peraturan Menteri Kominfo tentang penyelenggaraan Layanan Pos Universal yang selaras dengan Undang-Undang. Ruang lingkup dalam pekerjaan ini adalah:

1. Menginventarisasi permasalahanpermasalahan penyelenggaraan Layanan Pos Universal melalui metode kualitatif (wawancara), studi regulasi dan studi literatur juga mempertimbangkan rekomendasi BPK RI terhadap Penyelenggaraan Dana Bantuan Operasional LPU;

2. Menyusun analisa kebijakan Layanan Pos Universal menggunakan konsep Cost Benefit Analysis, Analisa Dampak Regulasi dan Manajemen Risiko dengan studi kasus Bantuan Operasional, Subsidi atau Metode Lainnya;

3. Menyusun rekomendasi metode penyelenggaraan Layanan Pos Universal sebagaimana hasil pada poin 2 (dua);

4. Menyusun Naskah Regulasi dan Legal Drafting Rancangan Peraturan Menteri Kominfo tentang Penyelenggaraan Layanan Pos Universal yang selaras dengan perundang-undangan dengan memperhatikan rencana model kebijakan pada poin 2 dan 3 .

Penentuan basis penyelenggaraan LPU, yakni amanat UU Nomor 38 Tahun 2009 yang berterkaitan POS; Rancangan naskah regulasi yang mencakup kriteria: mekanisme, perencanaan program, monitoring, pengawasan, verifikasi dan evaluasi sehingga terciptanya penyelenggaraan LPU yang akuntabel; Konsep dan metode perhitungan biaya atau Harga Pokok Produksi/ Layanan serta perhitungan distribusi pendapatan dengan pendekatan Transfer Pricing berdasarkan Produk; 


\section{METODE PELAKSANAAN}

Berdasarkan permasalahan diatas terlihat bahwa penyelenggaraan pos khususnya LPU merupakan penyelenggaraan yang penting dan cukup strategis dalam ikut serta mendukung dan menunjang ekonomi suatu bangsa. Metode yang dilakukan dalam PKM ini secara deksriptif dengan pendekatan survey ke beberapa penyelenggara pos. Pekerjaan inventarisasi titik layanan pos kepada penyelenggara pos sesuai dengan proposal yang dibuat termasuk pola kemitraan dapat dijabarkan sebagai berikut:

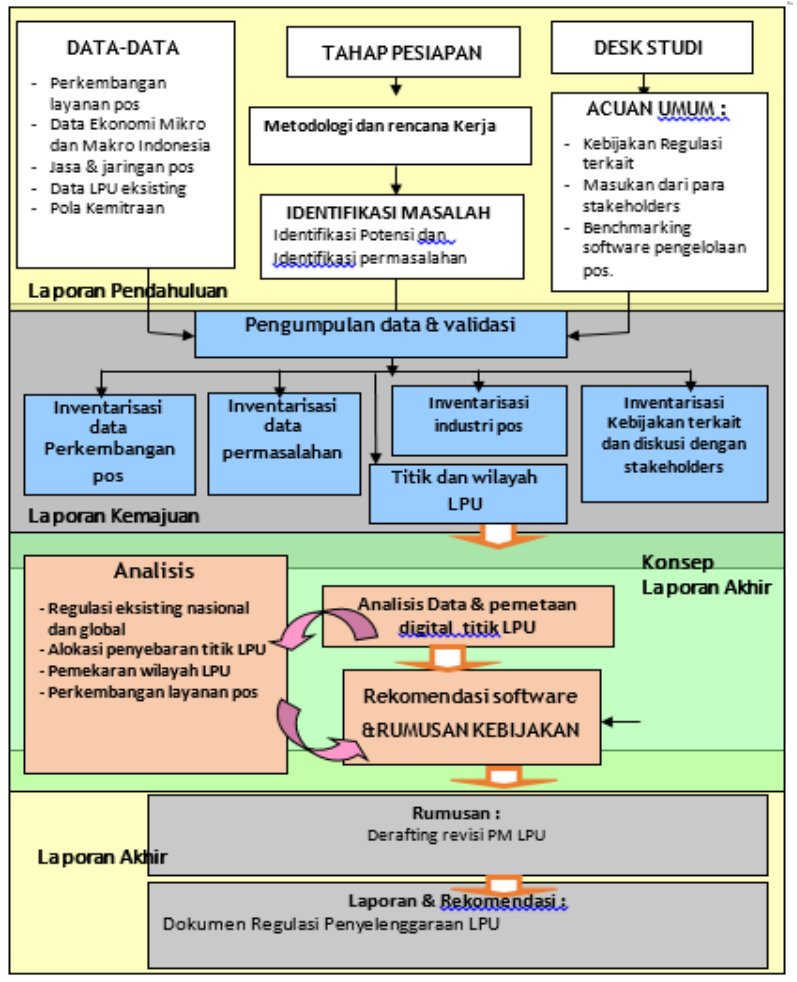

Gambar 1. Inventarisasi Titik Layanan Pos

\section{Jadwal Pelaksanaan Kegiatan}

Jangka waktu yang diperlukan dalam pelaksanaan pengerjaan penelitian ini adalah 2 (dua) bulan.
Tabel 2. Jadwal Pelaksanaan Kegiatan

\begin{tabular}{|c|c|c|c|c|c|c|c|c|c|}
\hline \multirow{2}{*}{ No } & \multirow{2}{*}{ Kegiatan } & \multicolumn{4}{|c|}{ Bulan 1} & \multicolumn{4}{|c|}{ Bulan 2} \\
\hline & & 1 & 2 & 3 & 4 & 1 & 2 & 3 & 4 \\
\hline \multirow[t]{4}{*}{1} & Persiapan dan Mobilisasi & & & & & & & & \\
\hline & Mobilisasi Tim \& Persiapan kickoff & & & & & & & & \\
\hline & Penyusunan Rencana Kerja & & & & & & & & \\
\hline & Metodologi Kerja \& sosialisasi & & & & & & & & \\
\hline \multirow[t]{5}{*}{2} & Pengumpulan Data dan Informasi & & & & & & & & \\
\hline & Identifikasi Permasalahan & & & & & & & & \\
\hline & Data Regulasi Terkait & & & & & & & & \\
\hline & Data Model trasnfer pricing & & & & & & & & \\
\hline & data keuangan & & & & & & & & \\
\hline \multirow[t]{9}{*}{3} & $\begin{array}{l}\text { Pengolahan data,perhitungan, Analisa } \\
\text { dan Rekomedasi }\end{array}$ & & & & & & & & \\
\hline & Analisis Regulasi eksisting & & & & & & & & \\
\hline & Analisa regulasi dan permasalahan & & & & & & & & \\
\hline & $\begin{array}{l}\text { Analisa pengujian model transfer } \\
\text { pricing LPU }\end{array}$ & & & & & & & & \\
\hline & Analisa masukan stakeholder & & & & & & & & \\
\hline & Rekomendasi & & & & & & & & \\
\hline & CBA analis dampak bantuan LPU & & & & & & & & \\
\hline & Manajemen risiko BO LPU & & & & & & & & \\
\hline & drafting Revisi PMLPU & & & & & & & & \\
\hline \multirow[t]{4}{*}{4} & Pembuatan Laporan & & & & & & & & \\
\hline & Laporan Pendahuluan & & & & & & & & \\
\hline & Laporan Kemajuan & & & & & & & & \\
\hline & Laporan Akhir & & & & & & & & \\
\hline
\end{tabular}

Peta Lokasi Mitra (termasuk jarak dari Unikom)

Mitra: PT Progressiva - Jl. Ternate No 1 Bandung 40115

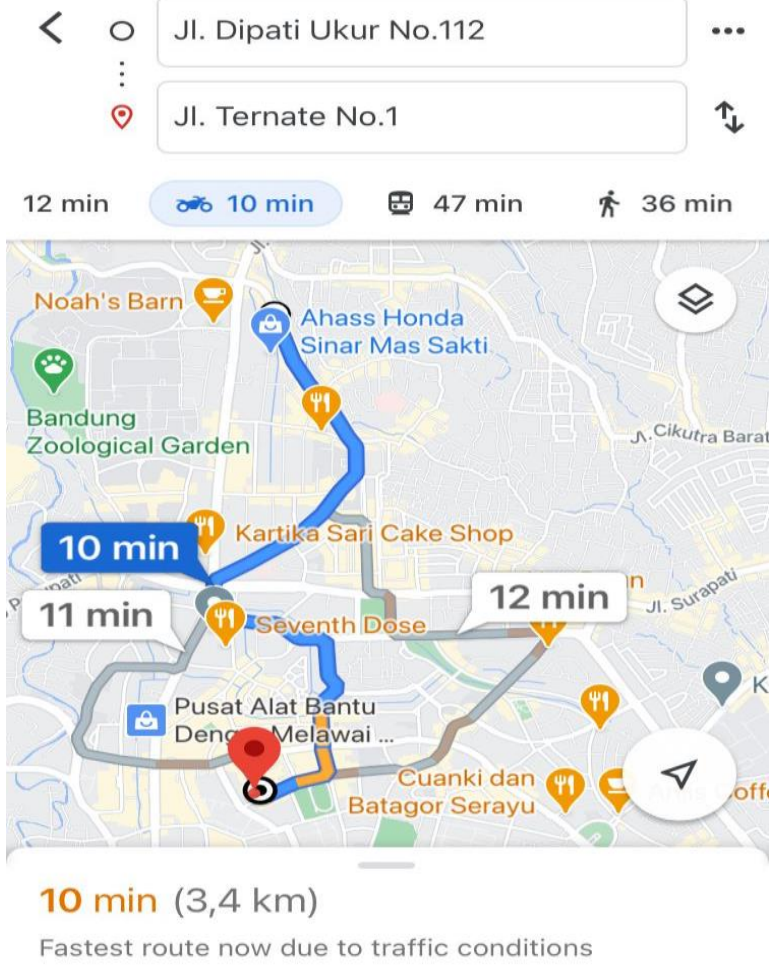

Gambar 2. Peta Lokasi Mitra 
Foto Kegiatan - Metode Pelaksanaan

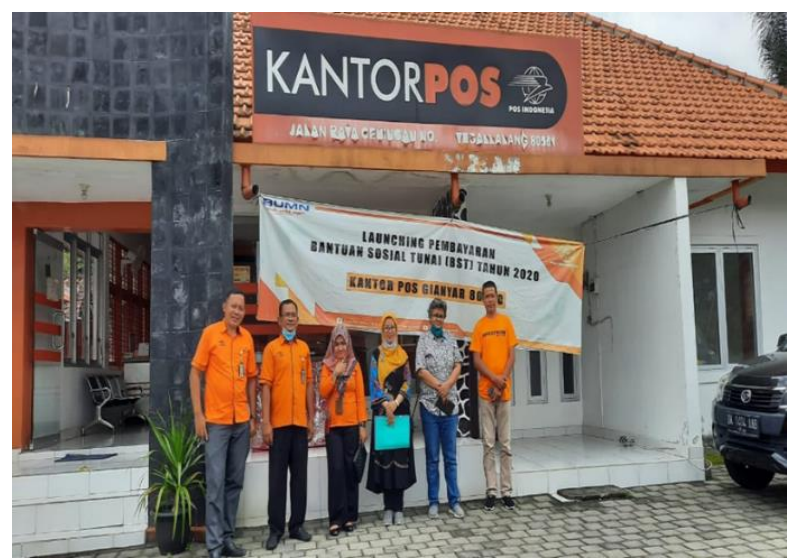

Gambar 3. Kegiatan Survey

\section{HASIL DAN PEMBAHASAN Layanan Pos Universal}

Layanan Pos Universal merupakan kewajiban pelayanan public di bidang pos yang diberikan oleh pemerintah untuk seluruh masyarakat diseluruh wilayah Indonesia agar dapat mengirim dan menerima layanan surat dan paket dari dan menuju seluruh dunia. Selain itu Layanan Pos Universal yakni sebagian program Rencana Pembangunan Jangka Menengah Negara yang mendukung pembangunan dan pertumbuhan perekonomian di seluruh Indonesia. Saat ini, Layanan Pos Universal dilaksanakan oleh operator yang ditunjuk oleh pemerintah dan diberikan Bantuan Operasional sebagai kompensasi atas penugasan tersebut, namun penyelenggaraan yang saat ini dilaksanakan belum sesuai dan praktiknya yang ditunjukan dengan temuan penyelengggaraan BO LPU dari Badan Pemeriksa Keuangan RI pada Laporan Hasil pemeriksaan atas Pengelolaan dan Pertanggungjawaban Keuangan BA 999.08 (Kementerian Kominfo) sehingga belum mencerminkan dukungan atas prinsip dasar kewajiban pelayanan public di bidang Pos.

\section{Konsep Public Service Obligation (PSO)}

Pemerintah dapat memberikan penugasan khusus kepada BUMN, guna menjalankan fungsi umum dan tetap memperhatikan maksud/ tujuan kegiatan BUMN tersebut (ayat 1). Setiap penugasan seharusnya mendapatkan persetujuan dari RUPS/menteri (ayat 2). Keberadaan dan operasional BUMN diatur dalam Undangundang Nomor 19 tahun 2003 tentang BUMN. Dalam undang-undang tersebut diatur bahwa tujuan pendirian BUMN adalah :

- Memberikan sumbangan bagi perkembangan perekonomian nasional pada umumnya dan penerimaan negara pada khususnya

- Mengejar keuntungan

- Menyelenggarakan kemanfaatan umum bagi hajat hidup orang banyak

- Menjadi perintis kegiatan usaha yang belum dapat dilaksanakan oleh sektor swasta dan koperasi

- Turut aktif memberikan bimbingan dan bantuan kepada pengusaha golongan ekonomi lemah, koperasi dan masyarakat

Framework PSO yang jelas dapat memberikan pilihan kepada Pemerintah untuk tidak melakukan jasa pelayanan umum yang telah dilakukan oleh pihak swasta, sehingga Pemerintah dapat berkonsentrasi pada pencapaian tujuan PSO [4].

\section{Gambaran Umum Pelaksanaan PSO}

Laporan keuangan, kinerja BUMN dalam menjalankan PSO, belum menunjukkan adanya kinerja yang baik secara menyeluruh. Gambaran kinerja kurang baik ini akhirnya berdampak pada citra perusahaan BUMN. Terkesan BUMN PSO identik inefisiensi dan korupsi oleh manajemen ataupun politikus dan birokrat. Dalam Tabel 2 dijelaskan kendala umum dalam pelaksaaan PSO. 
Tabel 3. Berbagai Kendala Umum Dalam Pelaksanaan PSO

\begin{tabular}{|c|c|c|}
\hline $\begin{array}{l}\text { Tahap } \\
\text { Perencanaan }\end{array}$ & $\begin{array}{l}\text { Tahap } \\
\text { Pelaksanaan }\end{array}$ & $\begin{array}{l}\text { Tahap } \\
\text { Evaluasi }\end{array}$ \\
\hline $\begin{array}{l}\text { Belum ada } \\
\text { kesamaan } \\
\text { persepsi terkait } \\
\text { pengertian/ } \\
\text { definisi PSO }\end{array}$ & $\begin{array}{l}\text { Belum } \\
\text { seragamnya } \\
\text { perhitungan } \\
\text { dasar kebutuhan } \\
\text { dana PSO } \\
\text { diantara BUMN }\end{array}$ & $\begin{array}{l}\text { Realisasi } \\
\text { kompensasi } \\
\text { penugasan } \\
\text { (PSO) dari } \\
\text { pemerintah } \\
\text { tidak } \\
\text { mencukupi, } \\
\text { pembayaran } \\
\text { dilakukan } \\
\text { setelah } \\
\text { dilakukan } \\
\text { verifikasi } \\
\text { oleh } \\
\text { Departemen } \\
\text { keuangan }\end{array}$ \\
\hline $\begin{array}{l}\text { Dasar penentuan } \\
\text { rute-rute } \\
\text { transportasi } \\
\text { yang di PSO-kan } \\
\text { belum jelas }\end{array}$ & \multirow{2}{*}{$\begin{array}{l}\text { Belum ada } \\
\text { pemisahan } \\
\text { laporan } \\
\text { keuangan antara } \\
\text { kegiatan usaha } \\
\text { yang di PSO kan } \\
\text { dan kegiatan } \\
\text { usaha non PSO }\end{array}$} & \multirow[t]{2}{*}{$\begin{array}{l}\text { BUMN } \\
\text { pelaksana } \\
\text { PSO } \\
\text { cenderung } \\
\text { tidak efisien } \\
\text { dan kurang } \\
\text { inovatif }\end{array}$} \\
\hline $\begin{array}{l}\text { Belum semua } \\
\text { kegiatan PSO } \\
\text { dilelang }\end{array}$ & & \\
\hline
\end{tabular}

\section{Penyelenggaraan LPU di Indonesia}

Untuk merealisasikan salah satu tujuan dari penyelenggaraan Pos yaitu terjaminnya penyelenggaraan layanan pos yang menjangkau seluruh wialayah NKRI, maka dilaksanakanlah program Layanan Pos Universal (LPU). LPU adalah layanan pos jenis tertentu yang wajib dijamin oleh pemerintah untuk menjangkau seluruh wilayah NKRI yang memungkinkan masyarakat mengirim dan/atau menerima kiriman dari satu tempat ke tempat lain di dunia. Saat ini penyelenggara Pos LPU adalah PT. Pos Indonesia dengan 2.357 KPC LPU (Kantor Pos Cabang Layanan Pos Universal) di tahun 2013.
Untuk menyelenggarakan LPU, Pemerintah menugasi Penyelenggara Pos. Pemerintah juga wajib menjamin terselenggaranya LPU di seluruh wilayah NKRI. Dalam mengaplikasikan LPU tersebut maka setiap perusahaan angkutan darat, laut dan udara wajib memprioritaskan pengangkutan kiriman LPU yang diserahkan oleh Penyelenggara Pos. Persyaratan penyelenggaraan LPU adalah :

- Adanya kepemilikan/ penguasaan Jaringan Pos pada tingkat wilayah penyelenggaraan LPU dan/atau di seluruh wilayah NKRI

- Adanya SDM berkompeten di bidang Penyelenggaraan Pos

- Adanya rencana kerja dan anggaran Penyelenggaraan Pos untuk LPU setidaknya paling singkat 5 (lima) tahun

- Adanya pernyataan kesanggupan memenuhi Standar Pelayanan LPU

- Adanya pernyataan kesanggupan melaksanakan Akta Perhimpunan Pos Dunia

Dalam menjamin LPU, pemerintah memberikan tugas Penyelenggara Pos untuk menjalankan LPU dan ketersediaan Bantuan Operasional LPU pada masing-masing Kantor Pos Cabang Layanan Pos Universal (KPC LPU). KPC LPU ditetapkan dengan kriteria sebagai berikut :

a. Dioperasikan maksimum oleh 2 (dua) orang pegawai;

b. Pendapatan KPC tidak layak secara usaha;

c. Berada di luar Ibukota provinsi dan Ibukota kabupaten/ kota

Pelaksanaan LPU disusun berdasarkan Perjanjian Kerja LPU dengan Direktorat Jenderal dan Penyelenggara Pos yang ditandatangani oleh Direktur Jenderal dan Direktur Utama Penyelenggara Pos/ Direksi yang ditunjuk sesuai dengan ketentuan UU [6]. (Permenkominfo, 2010) Perjanjian kerja tersebut memuat setidaknya :

a. Banyaknya jumlah KPC LPU

b. Jumlah Besaran Bantuan Operasional LPU

c. Koefisien Transfer Pricing per area layanan 

d. Cara pembayaran Bantuan Operasional LPU
e. Hak dan Kewajiban
f. Tolak ukur
g. Jangka waktu pelaksanaan
h. Sanksi
i. Penyelesaian perselisihan

\section{Biaya Penyelenggaraan LPU}

Berdasarkan Studi UPU tahun 2010, diperkenalkan 3 (tiga) bentuk perhitungan/ pemberian kompensasi LPU, yaitu:

a. State Funding;

Merupakan bentuk pemberian kompensasi LPU melalui pengajuan ganti-rugi (reimbursed) dari Penyelenggara LPU kepada Anggaran Pemerintah.

b. Pendanaan melalui kontribusi;

Semua Penyelenggara diwajibkan untuk melakukan kontribusi terhadap biaya penyelenggaraan LPU melalui pengaturan pembebanan yang seragam. Dalam bentuk ini semua penyelenggara (operator) termasuk penyelenggara LPU dibebani kontribusi yang sama pula.

c. Pendanaan melalui kontribusi bagi Operator yang tidak menyelenggarakan LPU;

Operator yang tidak menyelenggarakan LPU diharuskan berkontribusi, sedangkan untuk Penyelenggara LPU dibebaskan dari kontribusi.

\section{Interkoneksi Penyelenggaraan LPU}

Setiap penyelenggara Pos wajib menyediakan jaringan Pos sesuai dengan izin penyelenggaraannya. Dalam prakteknya, penyelenggara Pos dapat melakukan Interkoneksi dengan penyelenggara Pos lain untuk menjamin layanan pos di setiap daerah. Interkoneksi antar Penyelenggara Pos dilaksanakan mengambil konsep dan prinsip non-diskriminatisi, transparant, bertanggungjawab dan untungmenguntungkan. Setiap penyelenggara Pos diwajibkan untuk memiliki Interkoneksi LPU terhadap penyelenggara Pos lainnya. Dalam penyediaan Interkoneksi LPU, Penyelenggara Pos wajib memperhatikan hal berikut :

1. Adanya informasi secara terbuka tentang fasilitas yang dimiliki dan dapat dipergunakan oleh Penyelenggara Pos lainnya

2. Adanya prosedur dan tarif sesuai dengan Peraturan Menteri

3. Adanya daftar penawaran interkoneksi yang dipublikasikan dengan paling sedikit memuat:

- Jaringan yang ditawarkan

- Spesifikasi teknis interkoneksi

- Tarif interkoneksi

- Prosedur pelaksanaan layanan interkoneksi

- Tanggung jawab penyedia layanan interkoneksi

Penyelenggara Pos yang melaksanakan LPU dapat menerima Interkoneksi layanan pos komesial berdasarkan perjanjian. Layanan Pos Komersial adalah layanan Pos yang besaran tarif dan standar layanannya tidak ditetapkan oleh Pemerintah.

Penetapan tarif LPU didasarkan pada perhitungan:

- Biaya operasional penyelenggaraan layanan;

- Proyeksi peningkatan biaya untuk peningkatan kualitas pelayanan;

- Proyeksi pertumbuhan produksi;

- Daya beli masyarakat; dan

- Ketentuan dalam Akta Perhimpunan Pos Sedunia

\section{Transfer Pricing}

Transfer Pricing yakni mekanisme perhitungan aktifitas dilaksanakan setiap bagian perusahaan terhadap pelayanan jasa POS [2]. Aktifitas yang mendapat kompensasi pos, diantaranya :

1. Adanya Proses Pengumpulan (collecting)

2. Adanya Proses Pengolahan (Processing)

3. Adanya Proses Transportasi (Transportation) 


\section{Adanya Proses Pengantaran (Delivery)}

Seluruh biaya pelayanan dapat dikelompokan dalam 4 proses, sebagai berikut:

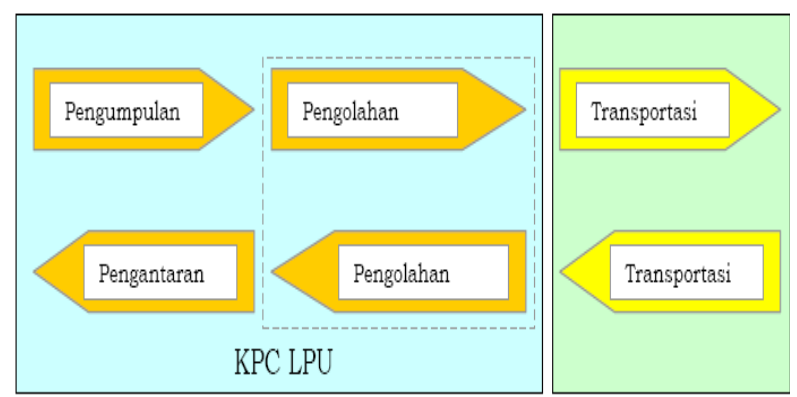

Gambar 4. Proses Pelayanan Pos

Aktifitas yang membentuk kesatuan aktifitas pada dasarnya dapat dibagi kedalam dua bagian besar, yaitu :

A. Aktifitas langsung

Aktifitas langsung yakni aktifitas yang berkaitan dengan pelayanan secara langsung, contoh pengumpulan, pengolahan, pengangkutan dan pengantaran.

B. Aktifitas tak langsung

Aktifitas tak langsung yakni aktifitas yang tidak berhubungan langsung dengan pelayanan seperti pemasaran, administrasi pelayanan pengawasan dan sebagainya. berikut :

Gambaran Transfer Pricing, sebagai

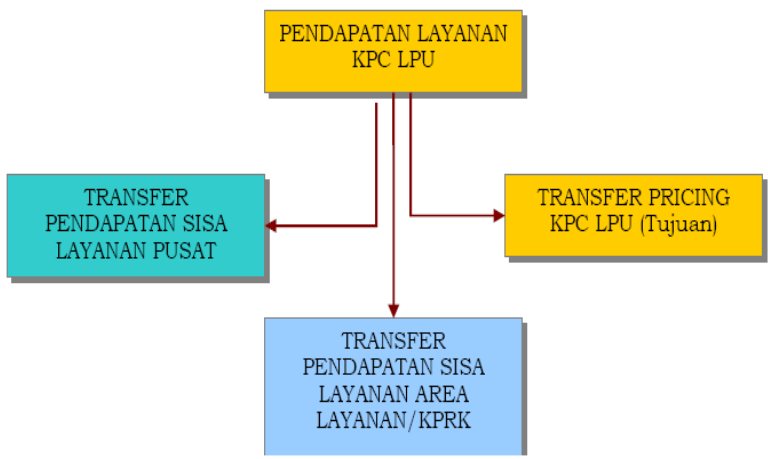

Gambar 5. Proses Aliran Transfer Pricing

Perhitungan biaya Bantuan Operasional melibatkan biaya langsung saja, sedangkan biaya tidak langsung, diperhitungkan dalam proses pendistribusian pendapatan hasil usaha. Pendapatan di KPC LPU meliputi pendapatan LPU dan Layanan Pos Komersial dan Layanan Transaksi Keuangan berdasarkan Fee. Metode Transfer Pricing sesuai pendapatan pelayanan jasa pos naik Pos Universal maupun Pos Komersial. Biaya usaha di pusat biaya KPC LPU terbagi 5 (lima) kelompok, berikut :

\section{Tabel 4. Biaya Usaha KPC LPU}

\begin{tabular}{|c|c|c|}
\hline & $\begin{array}{l}\text { Kelompok } \\
\text { Biaya }\end{array}$ & Uraian \\
\hline 1 & Pegawai & $\begin{array}{l}\text { - Pegawai diklasifikasikan } \\
\text { sebagai pegawai operasional } \\
\text { pelayanan di KPC LPU } \\
\text { berstatus pegawai tetap// } \\
\text { organik maupun/ kontrak } \\
\text { karya (TKK) dan outsourcing } \\
\text { - Biaya dihitung dari rincian } \\
\text { gaji dan tunjangan, dengan } \\
\text { komposisi biaya bulanan dan } \\
\text { non- bulanan } \\
\text { - Maksimum jumlah pegawai } \\
\text { terhitung yakni } 2 \text { orang }\end{array}$ \\
\hline 2 & Operasi & $\begin{array}{l}\text { - Biaya menjalankan pelayanan } \\
\text { di KPC LPU (biaya angkutan } \\
\text { untuk pick up barang dan } \\
\text { pengiriman jaringan tersier } \\
\text { - Biaya angkutan setempat } \\
\text { berpusat pada KPRK yang } \\
\text { dibebankan merata bagi } \\
\text { seluruh KPC LPU } \\
\text { - Biaya meliputi biaya } \\
\text { operasional lansung dan biaya } \\
\text { operasional penunjang }\end{array}$ \\
\hline 3 & $\begin{array}{l}\text { Pemeliharaan } \\
\text { Gedung }\end{array}$ & $\begin{array}{l}\text { - Biaya perbaikan ringan kantor } \\
\text { milik sendiri, (instalasi listrik, } \\
\text { air dan telepon, dll). }\end{array}$ \\
\hline 4 & $\begin{array}{l}\text { Administrasi } \\
\text { dan Umum }\end{array}$ & - Biaya umum dan manajerial \\
\hline 5 & $\begin{array}{l}\text { Penyusutan } \\
\text { Aktiva Tetap }\end{array}$ & $\begin{array}{l}\text { - Biaya usaha terjadi harga } \\
\text { perolehan aktifa tetap }\end{array}$ \\
\hline
\end{tabular}




\section{KESIMPULAN}

Dari pengamatan Hasil verifikasi Dokumen dan informasi dari PT. POS Indonesia, maka kami mengusulkan beberapa hal, Metode untuk pemberian Bantuan Operasional (BO) Layanan Pos Universal (PSO) yang diusulkan untuk direvisi pada PP adalah menggunakan 2 metode yaitu: metode Bantuan Operasional (BO) dan metode selisih tarif (Subsidi) dengan pertimbangan sebagai berikut:

a. Produk layanan Pos Universal (LPU) bukan merupakan produk utama yang dibutuhkan oleh semua orang, sehingga jumlah produksinya tidak banyak seperti pada produk yang dihasilkan oleh pertamina (BBM), PT. Pupuk Indonesia (pupuk) dan PT. KAI (jasa Transportasi kereta api). oleh karenanya apabila bentuk bantuan diberikan dalam bentuk metode selisih tarif saja (subidi) akan mengancam keberlangsungan usaha (going concern) PT Pos Indonesia karena walaupun layanan LPU diberikan subsidi jumlah jumlah biaya yang dikeluarkan akan lebih besar drpd jumlah pendapatan yang diterima sehingga potensi kerugian akan semakin besar. hal ini telah kami evaluasi berdasarkan hasil verifikasi dokumen yang dilakukan pada tahun 2019. data rekap terlampir.

b. Temuan terdapat bantuan Biaya Operasional yang usulkan melebihi kerugian yang di alami perusahaan, hal ini merupakan in effisiensi karena pemerintah memberi bantuan lebih dari yang dibutuhkan PT. POS untuk menutup kerugian. untuk mengantisipasi kondisis tersebut maka harus ada standardisasi thd komponen-komponen biaya yang harus ditetapkan oleh pemerintah/KOMINFO melalui Undang-undang. Misalnya gaji harus di standardisai sesuai dengan UMR masing2 regional dan yang diberikan hanya Gaji pokoknya saja, melainkan juga pemberian tunjangan akan dievaluasi ulang. Komponen biaya lainnya spt Beban Operasi (sewa Switching), langganan internet, Beban imbal jasa agen pos, sewa tanah dan Gedung kantor. Transport (biaya angkutan pos setempat, sewa kendaraan, BBM pelumas).

c. Mengeliminir biaya yang tidak seharusnya ditanggung oleh pemerintah. sbb:Gaji Pokok tidak seharusnya ditanggung oleh pemerintah, tpi kewajiban dr si pemberi kerja (cek Undang-undang), karena filosifi dari bantuan itu adalah membantu bukan menanggung seluruh pengeluaran. yang diusulkan untuk diberikan bantuan adalah tunjangan yang lebih spesifik ke layanan pos. misalnya ada akun baru tunjangan penyelenggaraan Pos Universal. karena terapat trend dari beberapa temuan yang menunjukan indikasi pegawai yang akan pension di tempatkan di KPC sehingga beban gajinya menjadi besar. Selama ini beban gaji kepala kantor KPC itu ditanggung oleh pemerintah.

\section{UCAPAN TERIMA KASIH}

Ucapan terima kasih kepada Universitas Komputer Indonesia (UNIKOM) yang telah memfasilitasi kegiatan Pengabdian Kepada Masyarakat sebagai salah satu Tri Dharma Perguruan Tinggi, melalui kerjasama antara Kominfo dan PT POS dalam kegiatan survey dalam upaya pendampingan kajian Revisi Peraturan Menteri Komunikasi dan Informatika Nomor 22 Tahun 2013.

\section{DAFTAR PUSTAKA}

[1] P. Dpr, "Undang-undang Tentang POS," 2009 (Issue April).

[2] I. Framework and \&. BEPS, " Transfer Pricing Guidance on Financial Transactions.," no. February, p. 8-10, 2020.

[3] Menkominfo, "Peraturan Menkominfo," Pmkominfo No 4 Tahun 2017. , 2017. [Online]. Available: https://ppidkemkominfo.files.wordpres 
s.com/2017/02/pm-kominfo-no-4-

tahun-2017.pdf.

[4] Permenhub, "Penyelenggaraan Kewajiban Pelayanan Publik. Page 1420.," 2016. [Online]. Available: https://www.insidehighered.com/view s/2011/08/22/public-service-obligation.

[5] Permenkominfo, "RPM Tarif Jasa Telekomunikasi," In konsultasi publik, 2008. [Online].

[6] Permenkominfo, Layanan Pos Universal LPU, 2010. 